\title{
Understanding the Nuances of Waishengren
}

History and Agency

\section{Dominic Meng-Hsuan et Mau-Kuei Chang}

\section{OpenEdition \\ Journals}

Édition électronique

URL : http://journals.openedition.org/chinaperspectives/5310

DOI : 10.4000/chinaperspectives.5310

ISSN : 1996-4617

Éditeur

Centre d'étude français sur la Chine contemporaine

Édition imprimée

Date de publication : 15 septembre 2010

ISSN : 2070-3449

\section{Référence électronique}


[

\section{Understanding the Nuances}

\section{of Waishengren}

History and Agency

DOMINIC MENG-HSUAN YANG AND MAU-KUEI CHANG

In the late 1940 s and early 50s, the world witnessed a massive wave of political migrants out of Mainland China as a result of the Chinese civil war. Those who sought refuge in Taiwan with the KMT came to be known as the "mainlanders" or "waishengren." This paper will provide an overview of the research on waishengren in the past few decades, outlining various approaches and highlighting specific political and social context that gave rise to these approaches. Finally, it will propose a new research agenda based on a perspective of migration studies and historical/sociological analysis. The new approach argues for the importance of both history and agency in the study of waishengren in Taiwan.

$\mathrm{T}$ he year 2009 marked the $60^{\text {th }}$ anniversary of the founding of the People's Republic of China (PRC). Sixty years, or yijiazi, completes a full cycle in traditional Chinese cosmology, and often signals the dawn of a new era. The origin of the PRC's glorious national saga began in 1949 with the victory of the Chinese Communist Party (CCP) over the Kuomintang (KMT) and the Republic of China (ROC). ${ }^{(1)}$ Contrasting with this triumphant euphoria are the stories of more than one million exiles of the civil war who left mainland China for Taiwan, Hong Kong, Vietnam, Burma, and other overseas locations. Positioned on the losing side of the PRC's national history, the émigrés were regarded as the enemies of "new China" (xin Zhongguo). They had been stigmatised as capitalist reactionaries, counter-revolutionaries, and stooges of American imperialism, among other things. ${ }^{(2)}$ While the fanfare of Chinese national pride in 2009 seemed to silence alternative voices, the publication of Big River Big Sea 1949 (Dajiang dahai 1949) by Lung Ying-tai, a renowned cultural critic and public intellectual in the Chinese world, became one of the notable exceptions. ${ }^{(3)}$ The book tells stories of ordinary people whose lives were affected by war and revolution in Taiwan, Hong Kong, and China during the 1940s and early 50s. ${ }^{(4)}$ The aim was to reconstruct the experiences of people from different walks of life who were caught up in cataclysmic events of war and political turmoil. By doing so, Lung evokes enduring memories of suffering and injustice that have for too long been swept under the carpet of national histories (both CCP and KMT). Big River Big Sea 1949 became an instant bestseller in Taiwan and Hong Kong but was banned in China for obvious reasons. ${ }^{(5)}$

1. The triumphant narrative of the PRC is perhaps best illustrated by an officially-sponsored epic The Founding of a Republic (Jianguo daye), which premiered in September 2009. The movie became an instant blockbuster due to official promotion and "star power." Many renowned international Chinese film celebrities and domestic stars participated in the film. The Founding of a Republic nevertheless sparked controversies over the nationality of the main actors and issues of historical interpretation.

2. In the 1950s and 60s, the official CCP organ Renmin ribao (People's Daily) called those who followed the KMT across the Taiwan Strait "remnants of Nationalist bandits" (Guomindang canfel) or "a treasonous bloc headed by Chiang Kai-shek" (Jiang Jieshi maiguo jituan). See "Wancheng shengli, gonggu shengli, yingjie yijiuwuling nian yuandan" (Achieving victory, consolidating victory, celebrating the New Year's Day of 1950), Renmin ribao, 1 January1950, p. 1; Qian Junrui, "Naqi wenyi wuqi jianjue huiji mei diguo zhuyi" (Pick up literary weapons, strike back at American imperialism), ibid., 24 June 1960, p. 7.

3. Lung was born in 1952 in south Taiwan to a military police family that relocated to the island with the KMT in 1949. Lung spent her formative years in Taiwan, but went to study in the United States, obtaining a PhD in English and American Literature from the University of Kansas. Later, she became a famous columnist and popular essayist known for her critical views of the KMT and social conditions in Taiwan during the 1980s. Lung returned to Taiwan in the late 1990s after living in Germany for some years. She took up an official post as the Director of the Cultural Affairs Bureau of Taipei (19992003) under Ma Ying-jeou's administration. She returned to writing afterwards and is now based in Hong Kong University.

4. For a sympathetic but somewhat critical review, see Leo Ou-fan Lee, "Book Reviews: Lung Ying-tai, Dajiang dahai-1949 (Big River, Big Sea-Untold Stories of 1949) and Chi Pang-yuan, Juliuhe (The River of Big Torrents)," China Perspectives, no. 81, 2010/1, pp. 114-116

5. The book sold well over 60,000 copies in Taiwan and Hong Kong by the end of 2009. In Taiwan, it became the number one bestseller among all types of books for that year. Although Big River Big Sea 1949 was officially banned in China, electronic versions are accessible on the Internet. 


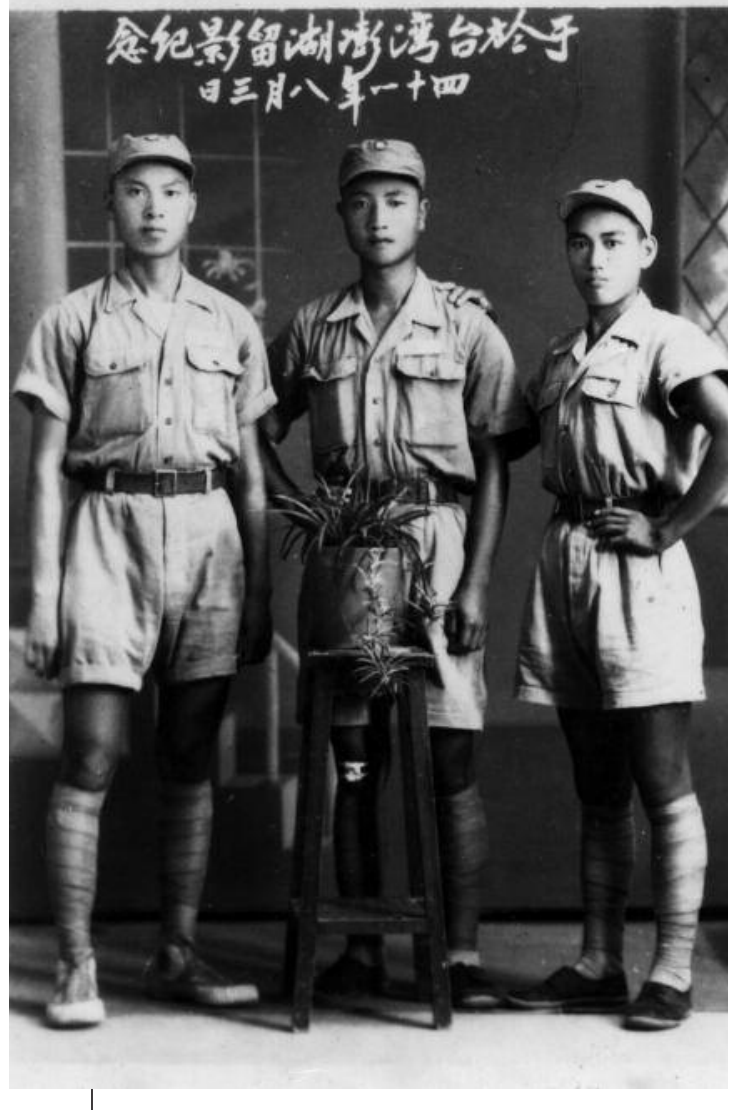

Three soldiers in their early 20s from Guangxi Province. They belonged to the KMT "Youth Army" (Qingnian jun). They were teenagers when they left school and home in 1944 to join the army and fight the Japanese. This picture was taken in Makung, Pescadores Islands, in 1952.

(c) Courtesy of Digital Archive for Memories and Narratives of Taiwan Waishengren

Lung's book is only one of the more prominent examples of a growing number of literary texts and cultural products by civil war exiles and their offspring in Taiwan since the late 1980s, often with a strong sense of nostalgia and self-affirmation. $\mathrm{No}_{0}$ table publications in the same year include Chi Pang-yuan's The River of Big Torrent (Jüliu he) ${ }^{(6)}$ and Chang Tien-wan's Searching for the Pacific (Xunzhao Taiping lun). ${ }^{(7)}$ Besides literary works, movies, TV dramas, and stage plays portraying the lives of mainland exiles in Taiwan, especially the stories of "military family village" (juancun), have also enjoyed critical and box office success. ${ }^{(8)}$ Outside literary, arts, and media circles, the production of oral history and preservation projects by local governments and civil associations such as "Waisheng Taiwanese Association" (Waisheng Taiwanren xiehui) have been quietly ongoing for some time. ${ }^{(9)}$

One of the main driving forces behind these endeavours seems to be a prevailing sense of crisis as a result of the processes of democratisation and "indigenisation" (bentuhua). ${ }^{(10)}$ Indigenisation is arguably the single most important political and cultural development in Taiwan during the past three decades. The process began in the late 1970s in the realm of literary production. During this time, fictional tales that reflected local conditions and grassroots sensitivity began to gain ascendancy over genres transplanted from

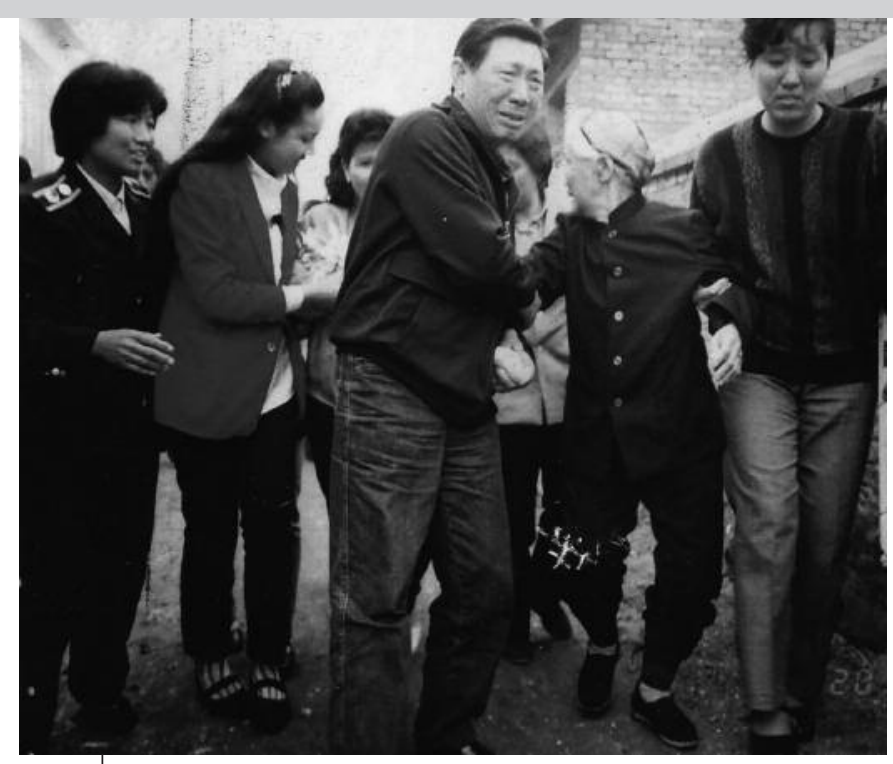

Retired ROC naval officer Chin Feng returned to Heilongjiang Province in May 1990 for a tearful reunion with his mother after 39 years of separation. Born and raised as a citizen of Manchukuo (1932-1945), Chin had never heard of the KMT or the CCP as a child. When the Korean War broke out, Chin joined the PLA expeditionary forces in part to save his family from Communist persecution at the age of 20 . He was captured by American troops in Korea and then chose to go to Taiwan with 14,000 former PLA soldiers in 1954.

○ Courtesy of Chin Feng; Digital Archive for Memories and Narratives of Taiwan Waishengren

China after 1949. In the 1980s and early 1990s, indigenisation went hand-in-hand with protests for democracy and the quest for ethnic and social justice, and contributed to the formation of contemporary party politics in Taiwan. Unfortunately, indigenisation also provoked backlashes from civil war migrants and their offspring, who often felt excluded. Faced with the fast-receding political dominance of the KMT

6. The River of Big Torrents is the memoir of Chi Pang-yuan, the daughter of a prominent Republican statesman from Manchuria, Chi Shih-ying (1899-1987). Chi Pang-yuan is also a venerated retired professor of literature from National Taiwan University and the mentor of many towering figures in Chinese and Taiwanese literature today. The River of Big Torrents is widely praised for its plain and candid narrative.

7. Chang Tien-wan's book explores the fate of the Pacific, an ocean liner that sank on the way to Taiwan on 27 January 1949. The incident took the lives of nearly 1,000 civil war refugees, including some prominent socialites. A documentary film under the same title was made in 2005 by the Democratic Progressive Party. Both the film and the book are based on interviews with survivors and victims' families.

8. Juancun were residential quarters constructed by the state to house military personnel and their families. In more recent years, two television soap operas-Goodbye, Loyalty Village Number Two (2005) and Story of Time (2008-2009) — have gained a wide following among audiences in Taiwan. The latter was the brainchild of famed television producer and second generation mainlander Wang Wei-chung (1957-). Story of Time not only achieved great ratings, but also led to a surge of juancun nostalgia among the mainlander community in Taiwan. In late 2008, Wang Wei-chung teamed up with acclaimed playwright Lai Sheng-chuan (1954-) to create a new play called Formosa Village Number One. While achieving great success at the box office and winning the accolades of critics in Taiwan, the performances were also well-received in China when the Mainland tour began in January of 2010. See Oscar Chung, "A Village on Stage," Taiwan Review, vol. 60, no.7, July 2010, pp. 60-65.

9. The Waisheng Taiwanese Association was founded in Taipei in 2004 by a coalition of mainlander intellectuals, artists, and journalists. The objective is to sponsor cultural activities and heritage preservation projects as a means of promoting "multiculturalism" and "bridging" the political/communal division resulting from "Blue versus Green" party politics in Taiwan.

10. For a comprehensive study of issues related to bentuhua, see John Makeham and Achin Hsiau (eds.), Cultural, Ethnic, and Political Nationalism in Contemporary Taiwan: Bentuhua, New York, Palgrave/Macmillan, 2005. 
and rising Taiwanese nationalism supported by native Taiwanese voters in the expansion of the electoral system, many mainlanders felt resentful and alienated as native Taiwanese increasingly treated them as "privileged outsiders." One reaction has been the construction of their own version of history and collective experience through cultural/literary productions, compilation of oral history volumes, and preservation projects such as the maintenance of some of the old juancun. ${ }^{\text {(II) }}$

Civil war migrants and their descendants are commonly referred to as "Mainlanders/mainlanders" or Waishengren/ waishengren in Taiwan. ${ }^{(12)}$ Since the early 1990s, Waishengren are often described in both official and popular discourses as one of the "four major ethnic groups" (sida zuqun) on the island. ${ }^{(13)}$ According to recent polls, about 10-13 percent of Taiwan's current residents can be regarded as people of mainlander origin. The other three major ethnic groups are "Hoklo" (Minnan), "Hakka" (Kejia), and "Aborigines" (Yuanzhumin). Hoklo constitute approximately 70 percent of the island's population, while Hakka and Aborigines account for about 15 percent and 2 percent, respectively. ${ }^{(14)}$ The first two are often lumped together as "native Taiwanese" or "local Taiwanese." They were the descendants of earlier migrants from China's Fujian and Guangdong Provinces and Flatland Aborigines (Pingpuzu/Pepo) who had lived under Japanese colonial rule (1895-1945), as opposed to Waishengren who arrived between 1945 and 1956.

Despite the recent increase in cultural activities of Waishengren searching for their "roots" and redefining their experiences in Taiwan through history, there has been little historical research on this group of people. Only a handful of published English monographs exist, and these treated Waishengren collectively as an ethnic group. ${ }^{(15)}$ They focused exclusively on contemporary developments, namely, how Mainlanders dealt with indigenisation and their identity crisis during the 1990s and 2000s. In these studies, key concepts such as ethnicity/ethnic relations, social class, tropism, and diaspora were raised. Publications in Taiwan have also been dominated by the issues of ethnic relations and national identity, though there is a growing number of "subgroup studies" looking into various social groups under the rubric of waishengren such as the old veterans (laobing), the juancun communities, Shandong exile students (Shandong liuwang xuesheng), soldiers and refugees stranded in Vietnam and Burma, and Chinese prisoners of war from Korea. This paper will provide a thematic overview of studies related to waishengren in Taiwan in the past few decades, mapping the field of existing knowledge, outlining various approaches, and illuminating the changing political and so- cial context that gave rise to these approaches. The review is by no means comprehensive, but aims at identifying major schools and representative studies. Based on these discussions, we will propose a new research agenda that takes a migrant perspective. More specifically, we intend to examine the subjective experiences and nuanced state-society relations engendered by war and involuntary relocation of a group of people and a political regime. The new agenda will illuminate the importance of both history and agency in the study of waishengren in Taiwan. Some preliminary findings in recent historical research will be presented to vindicate our proposal. These findings constitute a small part of an overarching project to explore the issues related to the colossal movement of people from mainland China to Taiwan from 1945 to 1956. In sum, we submit that the theorisation of waishengren experiences and identities requires broadbased historical and sociological research that pays attention to issues such as subgroup variations, generational difference, social class, and gender/sexuality.

\section{An emerging field of Mainlan- der studies? Approaches and theories}

\section{The Western pioneers: Political and social inequality and "ethnic relations" studies}

11. See Chen Chao-hsing, Juancun wenhua baocun daocha yanjiu diyiqi (An investigative report on the preservation of juancun culture, Vol. I), Taipei, Department of Cultural Affairs, Taipei City Government, 2002

12. Both capitalised and lowercase-Mainlanders/mainlanders and Waishengren/waishen gren-are used in this study in order to historicise these labels. As we shall see later civil war migrants and their offspring were not considered an "ethnic group" (Mainlanders/Waishengren) until after the late 1980s. Therefore, the capitalised terms are employed when describing developments after the1980s or when denoting "community," while the lowercase mainlander and waishengren are used when describing events before the 1980s and when trying to show the diversity within.

13. Wang Fu-chang, Dangdai Taiwan shehui de zuqun xiangxiang (Ethnic imagination in contemporary Taiwan), Taipei, Qunxue, 2003, p. 25. In a more recent study, Wang demonstrates that the discussion of "ethnicity" as an analytical concept in Taiwan's intellectual circles began in the late 1980s. See Wang Fu-chang, "You ruoyin ruoxian dao daming dafang: Taiwan shehuixue zhong zuqun yanjiu de jueqi" (From obscurity to fanfare: The rise of ethnic studies in Taiwan's Sociology), in Hsieh Kuo-hsiung (ed.), Qunxue zhengming: Taiwan shehuixue fazhan shi: 1945-2005 (Interlocution: A thematic history of Taiwanese sociology: 1945-2005), Taipei, Qunxue, 2008, pp. 447-521.

14. The percentages are approximated figures from various polls and surveys. For an example of a recent survey, see Council for Hakka Affairs of the Executive Yuan (ed.), Xingzheng yuan kejia weiyuanhui weituo yanjiu baogao: jiuqi niandu quanguo kejia renkou jichu ziliao daocha yanjiu (An investigative report of the Hakka population in Taiwan in 2008 by Council for Hakka Affairs of the Executive Yuan), Taipei, Council for Hakka Affairs of the Executive Yuan, 2008, p 71. In this report, the numbers are 70 percent Hoklo, 9 percent Mainlander, 14 percent Hakka, and 2 percent Aborigine. The remaining 5 percent of the surveyed population provided alternative answers or refuse to give a response.

15. These include the works of Stéphane Corcuff, Li Kuang-chun, and Scott Simon. They will be discussed in the next segment in further details. 
Mainlander studies did not begin with research on the experiences of the exiled community itself, but grew out of scholars' concern with the political and social inequality between post-war migrants and the local population. The discussion of "mainlanders" as a collective social group different from others social groups in Taiwan can be found in the writings of several Western scholars in the 1960s and 1970s, such as Mark Mancall, Richard Wilson, Sheldon Appleton, Wolfgang L. Gritchting, and J. Bruce Jacobs. However, these early researchers tended to identify mainlanders and other communities in Taiwanese as "cultural groups" or to separate them by "provincial origins." (16)

The first monograph that examined mainlanders and Taiwanese as two different "ethnic groups" was by American anthropologist Hill Gates in 1981. ${ }^{(17)}$ Entitled "Ethnicity and Social Class," the study was set up to dispute two anthropological approaches proposed by Gates' predecessorsthe historical idealist and the functional ecological. Using Taiwan's post-war development as an example, Gates suggested that the legacy of Japanese colonialism and the KMT policy of mainland recovery contributed to the creation of two different ethnic groups in an unequal relationship, with mainlanders dominating over the local Taiwanese. While this unequal relationship was apparent from the late 1940s to the early 1960s, the development of an export-oriented economy with mostly American investment since the mid1960s had altered the picture. A prosperous entrepreneurial middle class emerged that consisted of mostly native Taiwanese business owners. These Taiwanese business owners moved up the social ladder and joined a civil servant/managerial middle class comprised of mainlanders. ${ }^{(18)}$ Although the social data collected to support the main argument were somewhat sketchy, and the study paid little attention to the significance of cultural and linguistic issues in shaping social and political inequality, the overall interpretation by Gates of inter-group inequality and social transformation in post-war Taiwan is still illuminating. Gates' research was followed up in 1984 by another anthropologist, Susan Greenhalgh, who provided further analysis of the situation described by Gates. ${ }^{(19)}$

Despite the publication of Gates and Greenhalgh's studies, and despite the fact that a number of Western scholars had already pointed out apparent differences between civil war migrants and the local Taiwanese population before 1981, studies based on "ethnicity" or "ethnic relations" did not begin in Taiwan until the late 1980s and early 1990s. Because of KMT's anticommunist ideology and strong emphasis on national unity, research on inequalities and communal differences between mainlanders and local Taiwanese was neither encouraged nor sanctioned by the authorities. This was especially true if these were to be conceptualised in terms of social class and ethnicity. Therefore, ethnic relations studies in Taiwan began to spring up only with a change of political climate in the late 1980s. To understand the development of local scholarship, we need to first examine the origin and the change in use of the term "waishengren/Waishengren."

\section{The origin of "waishengren/Waishengren" and the emergence of "ethnic relations" studies in Taiwan}

Waishengren literally means "people from outside the province" (of Taiwan), a different meaning from its English translation "mainlanders" (people from mainland China). The term was already in use during the Anti-Japanese War (1937-1945) in mainland China. The Japanese invasion created a large number of war refugees who relocated to inland provinces and marginal regions of the country. Evidence from multiple historical sources indicates that local residents in Chongqing and Sichuan Province called the refugees pouring in from other provinces waishengren. ${ }^{(20)}$ The use of the term apparently extended into the civil war period. A cursory reading of the classified advertisement section of Central Daily News in the early 1950s suggests that civil war migrants in Taiwan routinely used the term waisheng to describe themselves. ${ }^{(21)}$ Also, during the earlier retrocession period (1945-1947), the use of the terms waisheng/bensheng (insider/outsider of the province) could also be observed in the antagonism between mainlander officials/intellectuals and the local Taiwanese elite over issues of political

16. Wang Fu-chang, "You ruoyin ruoxian dao daming dafang," art. cit. p. 477.

17. It should be noted here that Gates used the lowercase "mainlanders." See Hill Gates, "Ethnicity and Social Class," in Emily Martin Ahern and Hill Gates (eds.), The Anthropology of Taiwanese Society, Stanford, CA, Stanford University Press, 1981, pp. 241-281.

18. In the original article, Gates uses the term "new middle class" for mainlander civil servants and managers and "traditional middle class" for the Taiwanese small business owners. H. Gates, "Ethnicity and Social Class," op. cit., pp. 274-276.

19. Susan Greenhalgh, "Networks and Their Nodes: Urban Societies in Taiwan," China Quarterly, no. 99, 1984, pp. 536-540.

20. Chou Pi-se (ed.), Bo Yang huiyi Iu (The memoir of Bo Yang), Taipei, Yuanliu, 1996, pp. 140-143; "Yue jiaoyu ting jiangzhu liuxue waisheng xuesheng (...)" (Guangdong Bureau of Education sponsors waisheng students), Central Daily News, 17 February 1943, p. 6; "Minjiang liuyu de yugebing, huanzhe duo wei waisheng qingnian" (Most of the rain disease patients in the Min River area are waisheng youth), ibid., 6 January 1943, p. 6 . The other popular term for war refugees in Sichuan was "people coming down the river" (xiajiang ren).

21. Hundreds of personal ads looking for "outer province maids" (waisheng nuyong) posted in Central Daily News during 1950-1951 confirm the use of the term. 
representation, discrimination in official employment, and the dispute over the idea of "enslavement" (nuhua). ${ }^{(22)}$ Taiwanese discontent with mainlander rule eventually led to the well-known 228 Incident in 1947. There were actually other competing terms in the late 1940s and early 50s such as "mainland people" (dalu ren), "inland people" (neidi ren), and the derogatory "mountain people" (a shan) used by native Taiwanese. ${ }^{(23)}$ However, waishengren has outlasted the rest.

The main reason why the label waishengren came to represent civil war migrants and their offspring in Taiwan can be attributed to the emphasis on a person's "native place" (jiguan) in traditional Chinese society and the legacy of the civil examination system during the imperial dynasties. Jiguan was continued in the ROC Constitution drafted in 1947 to form a national assembly representing all of China. The system was maintained by the KMT after it relocated to Taiwan as the ROC state continued to categorise its citizens by their jiguan. However, as Wang Fu-chang has argued, jiguan was later used to legitimise the exiled KMT by maintaining the semblance of a government representing all of China with people and elected representatives from every province on the mainland. This would then justify the dominance of the mainlander elite in "national" politics in a "temporary" set-up before the KMT could retake China. ${ }^{(24)}$ Under the jiguan registration system, people were identified by their provincial origins and patrilineal descent. An emphasis was placed on the categorical difference between "natives of (Taiwan) Province" (bensheng) and "outsiders of the Province" (waisheng). ${ }^{(25)}$ In 1971, the ROC lost its seat in the United Nations to the PRC. The ensuing diplomatic debacle culminated in the United States' formal recognition of the PRC in 1979. During this time, the rise of a bensheng-dominated middle class in the aforementioned economic take-off and the emergence of a new generation of young dissident intellectuals formed what Hsiau A-chin called a "return to reality generation." They began to question the legitimacy of various claims made by the KMT. ${ }^{(26)}$ This led to a chain of events, including the rise of indigenisation and various social movements (labour, gender equality, environmentalism, Hakka/aboriginal rights, etc.), as well as the political opposition's demands for democracy in the 1980s. These developments eventually reshaped both the national and communal imaginations of the island's population in the late 1980s and early 1990s. ${ }^{(27)}$

In 1992, all congressional delegates elected in China were forced to step down to make way for the new congressional elections during the initial stage of the democratization process. The official distinction based on provincial origins was also abolished in hope of strengthening communal unity. However, as Wang Fu-chang has demonstrated, the years from 1987 to 1993 became an important turning point from "provincial origins" to "ethnic groups" (zuqun) in both academic inquiry and public discourse. ${ }^{(28)}$ Under the new discursive regime, the connotation and imagination of the term "waishengren" changed from denoting outsiders of a province in an exiled/virtual ROC state that included mainland China to "Waishengren" as an ethnic group in a multicultural and democratic society on the island of Taiwan. ${ }^{(29)}$ The paradigmatic shift in both official categorisation and public discourse in the late 1980s and early 1990s created a large number of "ethnic relations studies" (zuqun guanxi yanjiu). These studies offer a variety of comparisons, mostly on the socio-economic characteristics of the four newly recognised major ethnic groups - Hoklo, Hakka, Mainlanders/Waishengren, and Aborigines - through macro-level surveys. The earliest examples were Chang Mau-kuei and Hsiao Hsin-huang's essay on self-identification and views on

22. "Enslavement" or nuhua was an idea proposed by mainlander officials who were sent to govern Taiwan after the island's retrocession from Japan in 1945. Faced with the Japanisation of the islanders, the officials thought the Taiwanese were "enslaved" by a vicious and hostile culture and needed to be re-Sinicised. The local Taiwanese elite detested the label and protested vehemently against any utterance of it, considering it demeaning and discriminatory. For more, see Chen Tsui-lien, "Qu zhimin yu zai zhimin de duikang: yi yijiusiliu nian 'tairen nuhua' lunzhan wei jiaodian" (Decolonisation versus recolonisation: The debate over the "enslavement of Taiwanese" in 1946), Taiwan shi yanjiu (Taiwan Historical Research), vol. 9, no. 2, 2002, pp. 145-201.

23. "Mountain people" was a derogatory slang native Taiwanese used for newcomers from China after 1945. The term was derived from "Tang Mountain" (tangshan), a commonly used phrase by migrants during the Qing Dynasty when referring to mainland China. KMT misrule and the carpetbagging behaviour of waishengren before the 228 Incident also led Taiwanese to describe the newcomers as "pigs," in comparison to their former Japanese rulers who were like "dogs." This was emphatically illustrated by a popular staying during the retrocession period_- "the dogs leaving and the pigs coming" (gauki dilai).

24. Wang Fu-chang, "You 'Zhongguo shengij' dao 'Taiwan zuqun': hukou pucha jibei leishu zhuanbian zhi fenxi" (From Chinese original domicile to Taiwanese ethnicity: An analysis of census category transformation in Taiwan), Taiwan shehuixue (Taiwan Sociology), no. 9, 2005, pp. 100-110.

25. Wang Fu-chang, "You 'Zhongguo shengij' dao 'Taiwan zuqun'," p. 75. It should be noted here that instead of the official term benshengren, native Taiwanese prefer to regard themselves as "Taiwanese" (Taiwanren) or "indigenous people" (bendiren). Meanwhile, mainlanders often referred to their native provinces when identifying themselves. Therefore, waishengren had meaning only vis-à-vis benshengren/Taiwanren/bendiren.

26. Hsiau A-chin, Huigui xianshi: Taiwan yijiuqiling niandai de zhanhou shidai yu wenhua zhengzhi bianqian (Return to reality: Political and cultural change in the 1970s Taiwan and the post-war generation), Taipei, Institute of Sociology, Academia Sinica, 2008.

27. For social movements in the 1980s, see Hsu Cheng-kuang and Sung Wen-li (eds.) Taiwan xingxing shehui yundong (New social movements in Taiwan), Taipei, Juliu, 1990.

28. Wang Fu-Chang, "You ruoyin ruoxian dao daming dafang," art. cit., p. 510.

29. Another new term was proposed for civil war migrants and their offspring in the mid1990s: "new residents" (xin zhumin). However, it was sometimes confused with new immigrants from mainland China (mainlander brides) and Southeast Asia and did not become a commonly accepted term. 
intermarriage among university students in 1987, Tsai Shuling's research on the attainment of social status among the four major ethnic groups in 1988, and Wang Fu-chang's investigation of the Mainlander and Taiwanese divide in the employment practices of private enterprises in 1990. ${ }^{\left({ }^{30}\right)}$ Among the early studies, a notable exception was anthropologist $\mathrm{Hu}$ Tai-li's research on impoverished KMT veterans by the way of personal interviews in the late 1980s. ${ }^{(31)}$ The study not only constituted the first attempt to explore the life experiences and "ethnicity" of lower class mainlander soldiers, but also blazed a trail for mainlander "subgroup studies." These will be discussed in further detail in the next segment. ${ }^{(32)}$

Around the same time, another body of works focusing on electoral partisanship and national identity issues between Mainlanders and native Taiwanese also began to appear. These were pioneered by the studies of Lin Chia-lung in 1989 and Wu Nai-teh in 1992. ${ }^{(33)}$ Collectively, these studies demonstrated that most Waishengren remained loyal supporters of the KMT, while native Taiwanese formed the main constituency for the newly established Democratic Progressive Party (DDP), the opposition party to the KMT, which grew out of the democracy movement in the 1980s. The contested national identity-more specifically, the debate over reuniting with China or achieving de jure independence-has been identified as the most critical dividing issue between Mainlanders and native Taiwanese.

In 1992, a conference entitled "Provincial Origins, Ethnic Groups, and National Identity" was sponsored by the $\mathrm{Na}$ tional Institute of Policy Research (guojia zhengce yanjiu zhongxin) in Taipei. The conference resulted in the publication of an anthology of academic essays in 1993 edited by Chang Mau-kuei. The volume contained nine articles covering a broad range of topics relating to the application of an "ethnic relations" framework to the study of national identity and intergroup inequality, which were fast becoming politically sensitive and emotionally charged issues in Taiwan's ongoing democratisation process. ${ }^{(34)}$ It set an important precedent that was later followed by similar efforts throughout the 1990s and 2000s. ${ }^{(35)}$ However, the volume also provoked harsh criticism from those who were opposed to adopting an ethnicity framework to accommodate existing social divides and those who tended to view the rise of indigenous consciousness (bentu yishi) and Taiwan nationalism with a jaundiced eye. ${ }^{(36)}$ Despite objections from certain intellectual circles, research on ethnicity and ethnic relations continues to the present day.

\section{The rise of Waishengren identity transformation/identity crisis studies}

The establishment of "four major ethnic groups" in Taiwan under the precepts of multiculturalism as well as the study, commemoration, and reparation of injustices under KMT authoritarian rule (such as the 228 Incident and White Terror) since the early 1990s did not lead to more amicable relations among different groups on the island, especially between Mainlanders and native Taiwanese of Hoklo origin. Rather, the rise of party politics with constituencies divided along the ethnic lines aggravated the existing social division. From 1988 to 1993, Chiang Ching-kuo's (1910-1988) Taiwanese successor Lee Teng-hui (1923-) outmanoeuvred his conservative mainlander opponents in the KMT and put for-

30. Chang Mau-kuei and Hsiao Hsin-huang, "Daxue sheng de 'Zhongguo jie' yu 'Taiwan jie'-ziwo rending yu tonghun guannian de fenxi" (The "Chinese sentiments" and "Taiwanese sentiments" of university students-an analysis of self-identifications and views on intermarriage), Zhongguo luntan (China Tribune), no. 298, 1987, pp. 34-53; Tsai Shu-ling, "Shehui diwei de qude: shandi minke yiji waisheng zhi bijiao" (The attainment of social status: The comparison among Aborigines, Hoklo, Hakka, and Mainlanders), in Yang Kuo-shu and Chiu Hei-yuan (eds.), Bianqian zhong de Taiwan shehui, shangce (Taiwanese society in transition, Vol. I), Taipei, Institute of Ethnology, Academia Sinica, 1987, pp. 1-44; Wang Fu-chang, "Shengji ronghe huo geli? Taiwan qiye jingli renyuan de shengji zucheng" (Assimilation or segregation? Ethnic composition of managers in Taiwan's enterprises, 1978-1988), Zhongguo shehui xuekan (Chinese Journal of Sociology), no. 14, 1990, pp. 117-152.

31. Hu Tai-li and her assistants began to interview lower-class KMT veterans in the late $1980 \mathrm{~s}$ Her study results were published in both English and Chinese. See Hu Tai-li, "Ethnic Identity and Social Condition of Veteran-Mainlanders in Taiwan," Revue Europeenne des Sciences Sociales, vol. 27, no. 84, 1989, pp. 253-265; "Yuzai yu fanshu-Taiwan 'rongmin' de zuqun guanxi yu rentong" (Taros and sweet potatoes - ethnic relations and identities of "glorious citizens/veteran-Mainlanders" in Taiwan), Minzuxue yanjiusuo jikan (Bulletin of the Institute of Ethnology, Academia Sinica), no. 69, 1990, pp. 107-132.

32. Hu argues that the impoverished KMT soldiers possess strong "totemic sentiments" towards Chiang Kai-shek as their father figure. For more, see Hu Tai-li, "Ethnic Identity and Social Conditions of Veteran-Mainlanders in Taiwan," art. cit., pp. 258-260.

33. Lin Chia-lung, "Weiquan shicong zhengti xia de Taiwan fandui yundong-Minjin dang shehui jichu de zhengzhi jieshi" (The opposition movement in Taiwan under a patronclient regime-political explanation for the social base of the DPP), Taiwan shehu yanjiu jikan (Taiwan: A Radical Quarterly in Social Studies), vol. 2, no. 1, 1989, pp. 117143; Wu Nai-teh, "Guojia rentong he zhengdang zhichi: Taiwan zhengdang jingzheng de shehui jichu" (Party support and national identities: Social cleavages and party competition in Taiwan), Minzuxue yanjiusuo jikan (Bulletin of the Institute of Ethnology, Academia Sinica), no. 74, 1992, pp. 33-61.

34. Chang Mau-kuei (ed.), Zuqun guanxi yu guojia rentong (Ethnic relations and national identity), Taipei, Yeqiang, 1993.

35. See Shih Cheng-feng (ed.), Zuqun zhengzhi yu zhengce (Ethnic politics and policy), Taipei, Taiwan Association of University Professors/Qianwei chubanshe, 1997; Liao Ping-hui et al. (eds.), Chongjian xiangxiang gongtong ti: guojia, zuqun, xushu guoji xueshu yantao hui lunwen $j i$ (Reimagining Taiwan: Nation, ethnicity, and narrative-essays from an international symposium ), Taipei, Council for Cultural Affairs, Executive Yuan of the ROC, 2004.

36. A vocal attack came from sociologist Chao Kang, who is affiliated with Taiwan shehui yanjiu jikan (Taiwan: A Radical Quarterly in Social Studies). For more on Chao's criticism and Chang's response, see Chao Kang, "Xinde minzuzhuyi haishi jiude?" (New nationalism, or old?), Taiwan shehui yanjiu jikan (Taiwan: A Radical Quarterly in Social Studies), no. 21, 1996, pp. 1-72; Chang Mau-kuei, "Shi pipan yishi xingtai, yihuo liesha wupo?duiyu Chao Kang 'Xinde minzuzhuyi haishi jiude?' yiwen de huiying” (A critique of ideology or a witch hunt? A response to Chao Kang's "New nationalism, or old?"), ibid., no. 23, 1996, pp. 255-269. 
ward a series of constitutional reforms that established the premise of democratic institutions in contemporary Taiwan. In 1996, Lee became the first democratically elected president of the ROC amidst the threat of military exercises by the PRC in the Taiwan Strait. ${ }^{(3)}$ During his second term of presidency (1996-2000), Lee sped up implementation of a series of educational and cultural policies that contributed to the flowering of indigenisation projects, a process that Stéphane Corcuff called the "symbolic dimension" of democratisation. ${ }^{\left({ }^{38)}\right.}$ Some of the more notable changes included the removal of thousands of Chiang Kai-shek statues and portraits from schools and public places and placing new icons and pictures on banknotes (though the big Chiang Kai-shek Memorial Hall in Taipei still stands, and coins of 1, 5, and 10 NT Dollars engraved with Chiang's portrait are still in use). ${ }^{(39)}$ The various issues and effects of indigenisation have been sufficiently discussed by the essays in $\mathrm{Cul}$ tural, Ethnic, and Political Nationalism in Contemporary Taiwan: Bentuhua edited by John Makeham and Hsiau Achin in 2005. ${ }^{\left({ }^{(0)}\right)}$ Among the newly enacted measures, one of the most controversial has been the rejection of KMT official history and the construction of a new "Taiwan-centred history" (yi Taiwan wei zhongxin de lishi). This was illustrated by a dispute over the content of a new version of the middle school history textbook in 1997. The new textbook was criticised by ultra Chinese nationalists for being "proJapanese," "anti-KMT/anti-Chiang Kai-shek" and "de-emphasising the relationship between Mainland China and Taiwan," among other things. ${ }^{(41)}$

Many Waishengren, especially the older exiled generation, have observed these developments with heavy hearts. The 1997 textbook dispute was really only one of many instances of Mainlander discontent with the political and social transformation of Taiwan since the early 1990s as they felt increasingly offended or stigmatized by specific political discourse or political parties. ${ }^{(42)} \mathrm{On}$ one hand, the native Taiwanese majority of Hoklo descent saw the changes under indigenisation as long-awaited poetic justice after decades of KMT/Mainlander domination. On the other hand, Mainlanders saw the cherished memories of their family and community become politically incorrect and felt their dignity being trampled upon by the current discourse of indigenisation and Taiwan nationalism. ${ }^{(4)}$

Under these circumstances, another school of Mainlander studies emerged. These works attempted to investigate the transformation of Mainlander identity or the Mainlander "identity crisis" under the administration of two native Taiwanese presidents: Lee Teng-hui (1988-2000) and Chen
Shuibian (2000-2008). Among the main contributors were French political scientist Stéphane Corcuff, Taiwanese sociologist Li Kuang-chun, and Canadian anthropologist Scott Simon. In 2002, Stéphane Corcuff and Li Kuang-chun produced the first two major studies of the Waishengren identity transformation/identity crisis in the 1990s. The works appeared in a collective volume edited by Corcuff entitled Memories of the Future: National Identity Issues and the Search for a New Taiwan. ${ }^{(4)}$ Corcuff also published a modified new version of his 800-page French $\mathrm{PhD}$ dissertation in Chinese in 2004. ${ }^{(4)}$ The two authors had different research agendas and investigative methods. Corcuff employed a quantitative method by distributing a questionnaire to Waishengren in Taiwan in 1997 in order to find out whether Mainlanders retained their Chinese identity or had jumped on the bandwagon of localisation and self-determination. ${ }^{(46)}$

37. The episode came to be known as the Third Taiwan Strait Crisis. Provoked by Lee's 1995 visit to Cornell University, the PRC intended to use the threat of military exercises and missile tests to influence the election outcome in Taiwan. The tactic backfired. The United States dispatched two carrier groups to the sea near Taiwan to watch over the exercises, and Lee was elected president.

38. Stéphane Corcuff, "The Symbolic Dimension of Democratization and the Transition of National Identity under Lee Teng-hui," in Stéphane Corcuff (ed.), Memories of the Future: National Identity Issues and the Search for a New Taiwan, Armonk (NY), M.E. Sharpe, 2002, p. 73.

39. Ibid., pp. 80-83; 93-95.

40. J. Makeham and A. Hsiau (eds.), Cultural, Ethnic, and Political Nationalism in Contemporary Taiwan, op. cit.

41. Wang Fu-chang, "Why Bother about School Textbooks ?", in J. Makeham and A. Hsiau (eds.), Cultural, Ethnic, and Political Nationalism in Contemporary Taiwan, op. cit., pp. 73-88; S. Corcuff, "The Symbolic Dimension of Democratization and the Transition of National Identity under Lee Teng-hui," art. cit., pp. 83-92.

42. Lee Teng-hui's indigenisation policy not only led to a prevailing sense of alienation from mainstream society among the Waishengren community, but also contributed to the division of the KMT, with disaffected members forming the New Party (Xin dang) in 1993 and the People's First Party (Qinmin dang) in 2000. The vehement street protests against DPP candidate Chen Shui-bian's (1950-) victory in the 2000 presidential election was another prominent example.

43. For a good discussion of the issues of respect and recognition in Taiwan's current dispute over national identity, see Chang Mau-kuei and Wu Hsin-yi, "Guanyu minzu yu zuqun lunshu zhong de rentong yu qingxu: zunzhong yu chengren de wenti" (Identifications and emotions in national and ethnic discourse: the issues of respect and recognition), in Lin Chia-lung and Cheng Yung-nien (eds.), Minzuzhuyi yu liang'an guanxi (Nationalism and cross-strait relations), Taipei, Xin ziranzhuyi chubanshe, 2001, pp. 147-180.

44. See Stéphane Corcuff, "Taiwan's 'Mainlanders,' New Taiwanese?”, in S. Corcuff (ed.), Memories of the Future, op. cit. pp. 163-195; Li Kuang-chun, "Mirror and Masks: An Interpretative Study of Mainlanders' Identity Dilemma," in S. Corcuff (ed.), Memories of the Future, op. cit., pp. 102-122. It should be noted that there are other articles in this volume and a number of unpublished graduate theses in Taiwan around this time that have provided discussion of the Mainlander identity crisis. However, Corcuff and Li's works constitute the first two major publications that offer a systematic study and interpretation of the phenomenon.

45. Stéphane Corcuff, Fenghe rinuan: Taiwan Waishengren yu guojia rentong de zhuanbian (Gentle breeze and warm sunshine: The transformation of Mainlanders' national identity in Taiwan), Taipei, Yunchen wenhua, 2004.

46. Corcuff distributed more than 1,000 questionnaires, but only 286 were admissible to the study. Furthermore, approximately 70 percent of the sampled Mainlander population was born in Taiwan after 1950, and close to 75 percent of them had above college education. This raises a legitimate question of possible sampling bias in Corcuff's study. Ibid., 98-99; 152-157. 
Upon analysis of the data collected, Corcuff concluded that Waishengren exhibited a discernable tendency to identify with Taiwan instead of China under the presidency of Lee Teng-hui, a trend he called "tropism." ${ }^{(47)}$ According to Corcuff's data, "tropism" or "Taiwanisation" is more apparent among the younger generation of Mainlanders who grew up on the island. ${ }^{(48)} \mathrm{A}$ corollary to Corcuff's findings would be that Mainlanders as a collective whole have been indigenised, and many no longer seek reunification with China. However, recent quantitative studies in Taiwan, such as the one by Shen Hsiao-chi, tend to suggest differently. Shen demonstrates that while the number of Waishengren who consider themselves Chinese has shown a considerable decline, it has not been replaced by a substantially increased identification with Taiwan. Instead, there has been a noticeable increase in "double identity," which allows for the coexistence of both Chinese and Taiwanese identifications. According to Shen, dual identities should be understood and not necessarily regarded as a "political problem" as some may suggest. ${ }^{(49)}$

In contrast to Corcuff, Li Kuang-chun used personal interviews to investigate how Waishengren dealt with the changes under indigenisation. Based on the testimonies of 32 interviewees selected by stratified snowball sampling, $\mathrm{Li}$ showed that many of his informants would put on a "mask" or employ "impression management" when interacting with other groups on account of possible discrimination they might receive. Second-generation Mainlanders were usually more successful in adopting the masking strategy, since a lot of them speak Taiwanese. ${ }^{\left({ }^{50}\right)} \mathrm{Li}$ 's findings are supported and expanded by other studies. One recently published monograph by Sun Hung-yeh examines the response of secondgeneration Mainlanders to the social stigmatisation of their community. Sun identifies four different types of identity formation among his interviewees: those who stick to being Chinese, those who claim they are both Chinese and Taiwanese, those who consider themselves Taiwanese, and those who remain ambivalent and do not want to make a clear-cut statement on identity. ${ }^{\left({ }^{(1)}\right.}$

In 2006, Scott Simon offered yet another reading of the Mainlander identity dilemma. He considers the alienation of Waishengren from mainstream Taiwanese society as a form of "diasporisation." Seeing the KMT authoritarian rule on the island from 1945 to 1987 as a type of "colonialism," and making an interesting comparison with the decolonisation of South Africa, Simon argues that, in response to the rise of a new Taiwan-centred discourse and the loss of political and cultural privileges, Mainlanders are actively constructing a di- asporic identity to negotiate a new place in Taiwan. ${ }^{(52)}$ The move, he explains, would not only help erase the stigma of being associated with the KMT as foreign colonisers, but could also reposition them as a minority migrant group on the island with its own distinct history. ${ }^{(53)}$ The significance of Simon's contribution lies in theory-by formulating and elaborating concepts of colonialism and diaspora in the context of Mainlander experiences in Taiwan-though he was not the first to raise these issues. ${ }^{(54)}$

\section{Subgroup studies, refugees, deconstructive approach, and "diaspora"}

The studies looking into the identity transformation/identity crisis of Waishengren have contributed to a better understanding of the nuances within this "ethnic group." Generational difference is important. Many older civil war migrants remain steadfast to the KMT nationalist identity, while the younger generation exhibit obvious signs of indigenisation, or in the words of Stéphane Corcuff, "tropism." Nonetheless, this localised identity has both Chinese and Taiwanese elements. Furthermore, the Waishengren community seems to be constructing or reconstructing narratives of their own that are different from the KMT official history and the newly emerged Taiwan-centred history. Since the pioneering studies of Hill Gates and Susan Greenhalgh in the 1980s,

47. Tropism is a biological term used to describe a plant's growth in a certain direction in response to external stimuli such as light and water. The term was used metaphorically by Corcuff to describe the "Taiwanisation" of Mainlanders. S. Corcuff, "Taiwan's 'Mainlanders,' New Taiwanese?" op. cit., p. 188; S. Corcuff, Fenghe rinuan, op. cit., pp. 136-149.

48. S. Corcuff, Fenghe rinuan, op. cit., pp. 103-104.

49. Shen Hsiao-chi, "Gutu yu jiayuan: tansuo 'Waishengren'guojia rentong de liangge neihan" (Ancestral land and home: A probe into the two meanings of Mainlander national identity), in Chang Mau-kuei (ed.), Guojia yu rentong: yixie waishengren de guandian (Nation and identity: Perspectives of some mainlanders), Taipei, Qunxue, 2010, pp. 111146

50. Li Kuang-chun, "Mirror and Masks," op. cit., pp. 102-103; 116-118.

51. Sun Hung-yeh, "Waishengren dier dai guojia rentong" (The national identity of secondgeneration Mainlanders), in Chang Mau-kuei (ed.), Guojia yu rentong, op. cit., pp. 37-39.

52. Scott Simon, "Taiwan's Mainlanders: A Diasporic Identity in Construction," Revue européenne des migrations internationales, vol. 22, no. 1, 2006, p. 4. The comparison with South Africa is in response to an interesting and original proposition made by Wu Rwei-ren that the Mainlanders were like Afrikaners. Expanding on Wu's idea, Simon provided a penetrating analysis of the differences between "settler colonialism" and "state colonialism." See ibid., pp. 11-13.

53. Scott Simon, "Taiwan's Mainlanders," art. cit., p. 8.

54. The interpretive framework seeing the KMT as an "outsider/colonial regime" has its origin in Shih Ming, Taiwan ren sibainian shi (Four hundred year history of the Taiwanese people), San Jose, Paradise Culture Associates, 1980. Shih Ming's book was first published in Japan in 1962. Meanwhile, Taiwanese cultural anthropologist Chao Yen-ning was the first to propose that the first generation of mainlanders should be considered a "Chinese diaspora." See Chao Yen-ning, Daizhe caomao daochu lüxing: xing/bie, quanli, guojia (Wearing a straw hat and travelling around: Gender, power, and state), Taipei, Juliu tushu, 2001, chapter 7 . 
the categorisation and study of Waishengren as a distinct ethnic group in comparison with other ethnic groups in Taiwan along a series of socio-economic criteria such as social status, educational level, and occupation, inevitably led to the construction of a "privileged minority." The newly emerged Taiwan-centred history under indigenisation considers the island to have been ruled by successive "outsider/colonial regimes" (wailai zhimin zhengquan). ${ }^{(5)}$ In this narrative framework, the civil war migrants and their offspring in Taiwan are viewed as the instruments of a foreign regime that came to colonise the island in 1945. They had, until very recently, enjoyed disproportional state benefits and unfair advantages in education and official employment.

Yet this "ruling class versus oppressed native majority" dichotomy has overlooked diversity within the Waishengren community, especially in terms of social class, gender relations, and special groups. For example, the existence of a significant social underclass of impoverished/disfranchised KMT veterans raises legitimate questions about the homogenising ethnic group perspective as well as the colonialism narrative presented by Taiwan-centred history. During the past two decades, another school of mainlander studies thus grew steadily alongside the ethnic relations studies and the identity transformation studies. This field of research is comprised of a large number of monographs and oral history anthologies looking into different social groups, communities, and even stories of individuals. Collectively, these could be called "subgroup studies." The rise of subgroup scholarship is closely related to the emergence of a diasporic identity/narrative described by Scott Simon. ${ }^{(56)}$

The ethnographic fieldwork of Hu Tai-li examining the lives and group identity of impoverished KMT veterans mentioned earlier should be considered the pioneering study of subgroup scholarship. ${ }^{(57)}$ In the late $1980 \mathrm{~s}, \mathrm{Hu}$ and her assistants conducted interviews with hundreds of so-called "self-help veterans" (zimou shenghuo laobing) in Hualien in eastern Taiwan. Most of these people had joined the army as teenage boys, and while many had joined voluntarily, some were abducted by retreating KMT army divisions in the closing days of the civil war. Numbering in the tens of thousands, these individuals enjoyed few of the state benefits distributed to military officers and civil servants after they left the army with little choice. Most were discharged with no pension and little state assistance when the KMT streamlined the military in the late 1950s and early 1960s at the behest of American advisors. ${ }^{(58)}$ Many of the disfran-

chised veterans lived in abject poverty, but developed an emotional and ritualistic attachment to Chiang Kai-shek and other iconic symbols of the KMT, for which Hu coined the term "totemic sentiment." ${ }^{(59)}$ Because of poverty and alienation from mainstream society, a large number of these former soldiers remained single or had to marry women at the very bottom of social ladder-those who were prostitutes or suffered from physical or mental disabilities, as well as aboriginal women.

Apart from the study of disfranchised KMT veterans, there was also research on specific communities. One type of community that has received a lot of attention since the early 1990s is the "military family village" or juancun. They were first set up by various KMT military units stationed on the island in 1946. Only officers and non-commissioned officers with families were eligible. During its heyday, there were close to 900 such settlements throughout Taiwan and the

55. Shih Ming's original contribution in 1962 has spawned a large number of historical studies based on the colonialism framework, especially during the past two decades. In more recent years, literary scholars have applied postcolonial theory to Taiwan. See Chen Fang-ming, Houzhimin Taiwan: wenxue shilun jiqi zhoubian (Postcolonial Taiwan: Essays on Taiwanese literary history and beyond), Taipei, Rye Field Publishing, 2002.

56. Most of the researchers and oral historians engaged in subgroup studies are second or third generation waishengren.

57. Hu Tai-li, "Ethnic Identity and Social Condition of Veteran-Mainlanders in Taiwan," art cit., pp. 253-266; "Yuzai yu fanshu," art. cit., pp. 107-132.

58. Due to lack of evidence from military archives, Hu was unable to provide an approximate number of these "self-help" veterans. However, she alluded to the fact that a large percentage of the 122,000 military personnel retired by the KMT army before 1961 were "self-help" veterans. See Hu Tai-li, "Yuzai yu fanshu," art. cit., p 111.

59. Hu Tai-li, "Ethnic Identity and Social Condition of Veteran-Mainlanders in Taiwan," art cit., pp. 258-260; "Yuzai yu fanshu," art. cit., pp. 107-108. 


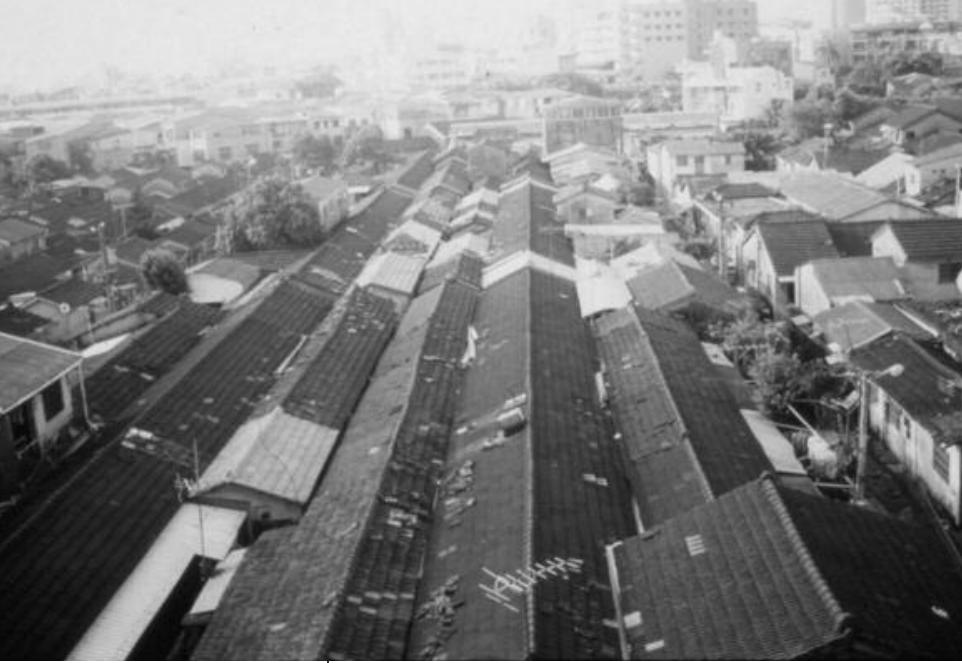

An aerial photo of juancun in Tainan City (1993). (c) Courtesy of Shang Tao-ming

Pescadores (Penghu) Islands. ${ }^{(60)}$ Since military personnel were almost exclusively mainlander males, juancun were thought to be "enclaves" of Waishengren even though many residents were native Taiwanese women who married the officers. Most juancun have been demolished since the 1990s to make way for city planning and the construction of new neighbourhoods. The demolition of juancun sparked a wave of nostalgia, calls for heritage preservation, and production of the TV dramas mentioned earlier. There exist a large number of theses and dissertations on individual juancun communities, but only a few were published. Two of the earliest monographs were Shang Tao-ming's study of the Lechun New Village in Tainan in 1995 and Chao Kang and Hou Nien-tsu's research on Chung-tai New Village (pseudonym) in Tai-chung in the same year. ${ }^{\left({ }^{(1)}\right.}$

Research on individual communities extended further to special groups such as the Shandong exile students, and the "second exodus" from Hong Kong, Vietnam, Burma, Korea, and the Dachen Islands. Shandong exile students, for example, were a group of approximately 8,000 students from several middle schools in Shandong Province who came to Taiwan in 1949. Their stories have been told by several oral history volumes and the monograph by Chen Yunchuan. ${ }^{(62)}$ These middle school students escaped from the advancing People's Liberation Army (PLA) and travelled thousands of miles to the south with their principals and school teachers, hoping the government would look after them and allow them to continue their education. However, at their temporary shelters in the Pescadores Islands the young students were pressed into the KMT army literally at gunpoint on 13 July 1949. Two principals, several teachers, and student leaders who protested were executed on charges of being Communist spies, while the rest were cowed into submission after some recalcitrant students were tortured. As victims of KMT state violence, and viewed with a jaundiced eye because of their "history," the young students showed remarkable resilience. Many worked their way up to the top of

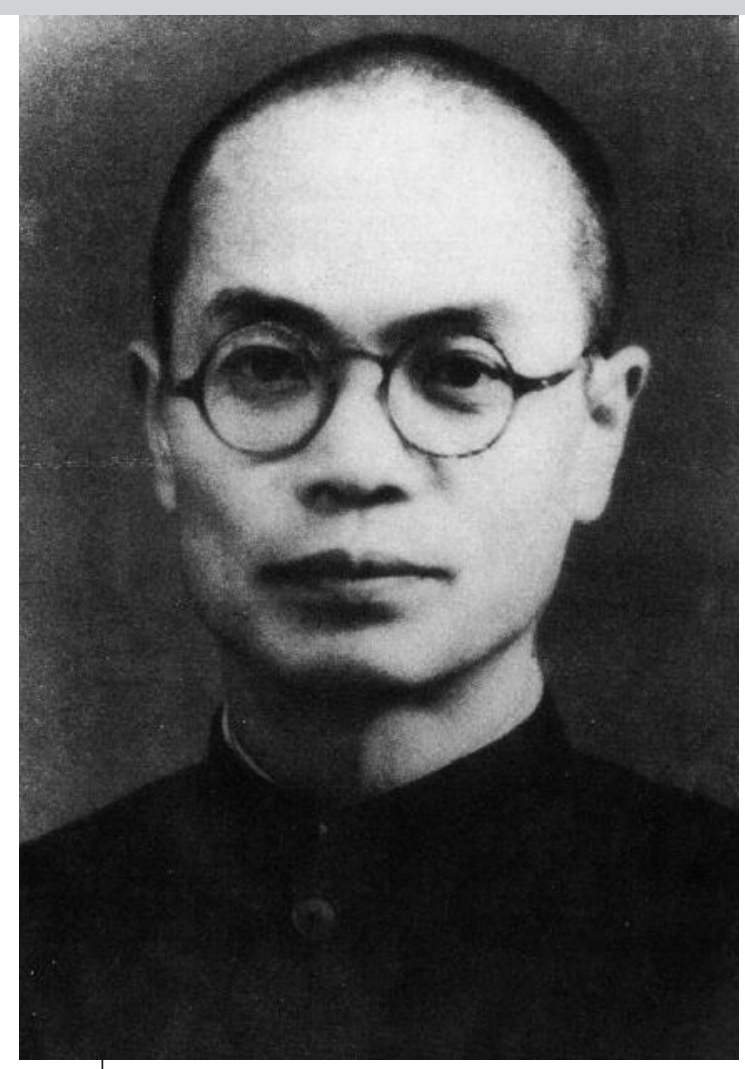

Chang Min-chih, principal of the United High School of Yantai, age 43, was framed as a Communist spy and executed in Taipei in 1949. Chang had led some 8,000 Shandong exile students to seek refuge in the south. He died trying to protect the students from being drafted into the army against their will. Several of his colleagues and some student leaders were also implicated in the case and executed. The case marked one of the earliest instances of White Terror in Taiwan.

(c) Courtesy of Hsieh Tsung-min; Digital Archive for Memories and Narratives of Taiwan Waishengren

Taiwan's social ladder. They formed a unique esprit de corps because of the traumatic memory of exile and injustice suffered at the hands of the state. Similar group identities could be found in the "second exodus" from Hong Kong (19501957), Burma (1953-1954; 1961), and Vietnam (1953), as well as the PLA soldiers captured by American forces dur-

60. Some of the early juancun were converted from empty Japanese facilities, but most were built from 1956 to 1980 with US military aid, special government revenue, and donations from the general public. According to statistics released by the KMT military in the 1980s, there were 888 "old" juancun in Taiwan, with close to 110,000 households. See Ho Si-mi, Taibei xian juancun daocha yanjiu (An investigative study of military family villages in Taipei County), Banciao, Cultural Affairs Bureau of Taipei County, 2001, pp. 19-23.

61. Shang's master's thesis was produced in 1995. However, it was not published until 2010. See Shang Tao-ming, "Juancun jümin de guojia rentong" (The national identity of military family village's residents), in Chang Mau-kuei (ed.), Guojia yu rentong: yixie waishengren de guandian, op. cit., pp. 3-30; Chao Kang and Hou Nien-tsu, "Rentong zhengzhi de daizui gaoyang-fuquan tizhi ji lunshu xia de juancun nüxing" (The scapegoats of identity politics: Women under patriarchal discourse in local community), Taiwan shehui yanjiu jikan (Taiwan: A Radical Quarterly in Social Studies), no. 19, 1995, pp. 125-163.

62. Wang Pei-wu et al., Shizijia shang de xiaozhang-Chang Min-chih furen huivilu (Principal on the cross-the reminiscences of Ms. Chang Min-chih), Taipei, Wenjing chubanshe, 1999; Tao Ying-hui and Chang Yu-fa, Shandong liuwang xuesheng shi (The history of Shandong exile students), Taipei, Shandong wenxian she, 2004; Chen Yunchuan, "Penghu qianxiang-Shandong xuesheng liuwang zhi lu" (The gunshots on Pescadores Islands- the road of exile for the Shandong students), in Chang Mau-kuei (ed.), Guojia yu rentong, op. cit., pp. 149-209. 
ing the Korean War who "chose" to go to Taiwan (1954) and the evacuees from the Dachen Islands (1955). The first two were considered by both the United Nations and the KMT as "refugees." The experiences of these groups were quite different from those who came in 1949, and also from each other. The nuanced stories of these communities have been explored in recent years by the works of Hu Chun-hui, Meng Chih-hui, Huang Hsiang-yu, Shen Hsing-yi, and Ko Kai-pei. ${ }^{(63)}$

Among the studies that focused on individual life stories, anthropologist Antonia Chao's (Chao Yen-ning) research on first generation mainlander women from different class backgrounds was particularly intriguing for presenting a "gendered" deconstructive perspective against the earlier ethnic relations and identity crisis studies. In a highly original contribution in 2001, Chao considers ethnicity framework as a derivative of male-centric nationalistic grand narrative. ${ }^{(64)}$ For her, the most important issue is neither ethnicity/identity nor nationalism, but "power" and "hegemonic domination," namely, the suppression of individual subjectivity by the patriarchal and nationalistic apparatus. An emphasis is put on the repression of sensuality and individual autonomy over their own bodies. The point is argued forcibly by the idea of "banished uterus" (liuwang de zigong) as Chao strives to reconstruct the individual agency of exiled mainlander women under the structure of national/patriarchal dominance. ${ }^{(5)}$ Chao's research later expanded to the exile experiences of lower-class mainlander veterans and the relationship between these old and impoverished former soldiers and their "new" spouses from China, with an emphasis on the spouses' agency and civil activism. ${ }^{(6)}$ Chao should also be recognised as the first scholar to introduce "diaspora" (Iisan) as a possible analytical concept to examine civil war migrants in Taiwan on account of a prevailing sense of uprootedness they felt in the endless search for belonging. The research of Antonia Chao, combined with the aforementioned works of $\mathrm{Hu}$ Tai-li, inspired a whole new field of research on the unique veteran/Aborigine communities in eastern Taiwan. In more recent years, the study was taken up by professors and students at the National Dong Hwa University in Hualien. ${ }^{(67)}$ Some of the best works in this line of research are unpublished theses produced by graduate students. ${ }^{(68)}$

\section{History and agency}

The investigative framework based on "ethnicity"-namely, the ethnic relations studies and the identity transformation/crisis studies-provides only one of the im- portant ways to examine the communal divide in contemporary Taiwan. The contribution by Chao Yen-ning and the rest of the subgroup scholarship demonstrates the importance of both history and agency in understanding the nuances of waishengren. Though constantly denied by different authors, the ethnicity framework leads to homogenisation and generalisation-seeing civil war migrants and their offspring as a privileged ruling minority and overlooking the important class difference within as well as the complex relationship between the KMT party-state and the migrant community in the past. Furthermore, human agency is also absent from most studies based on ethnicity. ${ }^{(69)}$ Even those who have considered waishengren as an "ethnic group" with recognisable collective identity or consciousness would concede that the existence of an ethnic or cultural group called Waishengren is not something civil war migrants and their

63. Hu chun-hui, Xianggang diaojingling ying de dansheng yu xiaoshi: Chang Han-sung deng xiansheng fangtan lu (The reminiscences of Chinese at Rennie's Mill Camp, Hong Kong, 1949-1997), Hsintien, Academia Historica, 1997; Meng Chih-hui, “'Baiyi fengqing' yu xunchang baixing de shenfen huanbian" (The change of identity between "Baiyi fashion" and ordinary civilians), in Chang Mau-kuei (ed.), Guojia yu rentong, op. cit., pp. 211236; Huang Hsiang-yu, "Zhiyue junmin zhi jieyun lai Tai, 1949-1953" (The transportation of soldiers and civilians from Vietnam to Taiwan, 1949-1953), Guoshiguan xueshu jikan (Bulletin of Academia Historica), no. 11, 2007, pp. 143-188; Sheng Hsing-yi, "Yiwang siqian ge zhengren: Hanzhan shiqi 'fangong yishi' zhi yanjiu" (Fourteen thousand witnesses: The study of "anticommunist patriots" during the Korean War), Master's thesis, Taipei, Department of History, National Taiwan Normal University, 2007; Ko Kaipei, "Dachenren yimin jingyan de rentong licheng" (The migrant experience and identity of Dachen Islanders), Master's thesis, Hualien, Department of Multiculturalism and Education, National Hualien Teacher's College, 2003.

64. Chao Yen-ning, Daizhe caomou daochu lüxing, op. cit, chapter 7.

65. Ibid., pp. 219-236.

66. Chao Yen-ning, "Jiaguo yuyan de gongkai mimi: shilun xiajieceng Zhongguo liuwang zhe ziwo xunshi de wuzhixing (Nationalistic language as an open secret: Diaspora, cultural citizenship, and the materiality of mainlanders' self-narratives), Taiwan shehui yanjiu jikan (Taiwan: A Radical Quarterly in Social Studies), no. 46, 2002, pp. 45-85; "Gongmin shenfen, xiandai guojia yu qinmi shenghuo: yi laodanshen rongmin yu 'dalu xinniang' de hunyin wei yanjiu anli" (The modern state, citizenship, and intimate life: A case study of Taiwan's glorious citizens and their mainland wives), Taiwan shehuixue (Taiwanese Sociology), no. 8, 2004, pp. 1-41.

67. Hsia Li-ming, "Xiangguan hechu, zhichi tianya: guojia zhipei, geren zaofeng yu Chishang pingyuan sange waisheng rongmin de difang rentong" (Searching for home at the other end of the world: State dominance, personal experience, and the local identity of three mainlander veterans living in the Chishang plain), Dong Taiwan Yanjiu (Journal of Eastern Taiwan Studies), vol. 7, 2002, pp. 45-66

68. See Li Chi-ping, "'Yubing yu nong' de dongbu tuifuhui laobing-yige tunken de huolishi” ('Military farm colonies' and the veterans settled by the Veterans Affairs Commission in the east-a live history of frontier cultivation), Master's thesis, Hualien, Institute of Ethnic Relations and Culture, National Dong Hwa University, 1997; Lai Chin-hui, "Zuqun tonghun yu zuqun guan-Siji xincun Yuanzhumin funü de jingyan" (Ethnic intermarriage and ethnic identity - the experiences of aboriginal women in New Four Seasons Village), Master's thesis, Hualien, Institute of Ethnic Relations and Culture, National Dong Hwa University, 1998; Wu Ming-chi, "Shiluo de huayu—Hualian waisheng laobing de liuwang chujing jiqi lunshu" (Lost words: The exile conditions and discourse of mainlander veterans in Hualien), Master's thesis, Hualien, Institute of Ethnic Relations and Culture, National Dong Hwa University, 2001.

69. An exception would be Li Kuang-chun's research on how individual mainlanders interacted with other social groups. See Li Kuang-chun, "Mirror and Masks," op. cit., pp. 102-122. 
offspring themselves would easily agree upon, especially among the older generation. ${ }^{(70)}$ Despite the fact that other communities on the island perceive post-war migrants as a distinct group, the act of arbitrarily classifying people without considering their own perceptions and without making a serious endeavour to understand their histories and subjectivities is still questionable.

Although waishengren received disproportionate state benefits because a large number of them worked in the civil service or served in the military and enjoyed cultural/linguistic advantages, and hence better life chances over native Taiwanese and Aborigines, their relationship with the migrant party-state has been more complex and less cordial or reciprocal than commonly perceived. ${ }^{(71)}$ Besides the aforementioned subgroup studies, recent research by scholars of transitional justice in Taiwan indicates that waishengren represented approximately 40 percent of known White Terror (baise kongbu) victims while accounting for only 10 to 15 percent of the total population on the island. Waishengren cases were concentrated in the early 1950s. ${ }^{(72)}$ Based on this new evidence, we can posit that in early post-war Taiwan, the KMT may have purged and disciplined the migrant community with more rigor and intensity than it applied to native Taiwanese. From the perspective of KMT officials, the chaotic mass exodus with swarms of unchecked refugees and troops pouring onto the island every day from 1948 to 1950 provided great opportunity for Communist infiltration. ${ }^{(73)}$ Furthermore, dissident intellectuals, influential provincial leaders, and rival forces within the KMT needed to be brought under tighter control and (re)indoctrinated with KMT ideology and the personal cult of Chiang Kai-shek. Therefore, the hunt for "Communist spies" and suppression of political dissidents had a greater overall impact on civil war migrants than on the local population during the early post-war years.

The study of White Terror constitutes only one of the many recent empirical findings that problematise the "ethnic" dichotomy between "Waishengren" and "native Taiwanese" and the current articulation of Taiwan-centred history, which tends to exclude the experiences of mainlanders, however unintentionally. For instance, the conditions created by war and exile as well as memories of war and exile were among the crucial factors that shaped and continue to shape the experience and self-identification of waishengren in Taiwan and must be researched to obtain a more accurate picture of all the nuances of the waishengren. Dominic Meng-hsuan Yang's recently published monograph has demonstrated the detrimental effects of the exodus on the social and commu- nal life of civil war migrants in early post-war Taiwan. In the 1950s, the migrants had significantly higher crime rates, suicide rates, and cases of mental illnesses compared to native Taiwanese. ${ }^{(74)}$ While the statistical data provide greater social context for the communal dislocation experienced by civil war migrants, the tremendous number of personal ads searching for lost relatives and friends (xunren qishi) posted in Taiwan's largest daily newspapers such as Central Daily News and United Daily News in the late 1940s and early 1950s add human dimension to the story. Each ad not only represents personal tragedy, but also offers concrete evidence of the break-up of family bonds and social networks in exile. These traumatic experiences became personal stories narrated by the protagonists of Lung Ying-tai's Big River Big Sea 1949 as well as numerous memoirs and oral history volumes produced by mainlanders since the late 1980s, when democratisation and the lifting of the ban on travel to mainland China led to an outpouring of repressed memories and emotional feelings. The breakdown of community and alienation from the culturally semi-Japanese local population contributed to the growing dominance of the KMT party-state in the lives of civil war migrants as they established new families and rebuilt communities in exile. While the lives and careers of the KMT's ruling elite were inevitably intertwined with the party, those who could be considered "victims" of the party-state, such as the Shandong exile students and the kidnapped/disfranchised veterans, also developed strong

70. S. Corcuff, “Taiwan's 'Mainlanders,' New Taiwanese?”, op. cit., pp. 168-169.

71. It is interesting to note here that a very recent study by two young sociologists suggests that fluency in "Taiwanese" (Hoklo/Minnanhua) can also be an advantage in small businesses and large/medium enterprises. See Chen Wan-chi and Wen Yu-wen, "Gung siami ue gangwu yaugin? Yuyan ziben dui zuqun jian zhiye qude chayi de yingxiang" (Does language matter? Ethnicity, linguistic capital, and occupational attainment in Taiwan), Taiwan shehui xuekan (Taiwanese Journal of Sociology), no. 44, 2010, pp. 1-54.

72. The majority of known White Terror cases occurred in the 1950s and 60s (75 percent). See Wu Nai-teh, "Transition without Justice, or Justice without History: Transitional Justice in Taiwan," Taiwan Journal of Democracy, vol. 1, no. 1, 2005, pp. 93, 100.

73. During the course of the civil war, waves of refuge-seekers began pouring into Taiwan in late 1948. Facing a "refugee crisis" and fearing the infiltration of Communist spies, the governor general Chen Cheng (1898-1965) implemented strict entrance regulations in February 1949. However, the new measures did not stem the tidal wave of refugees and defeated troops. See Hsueh Yueh-shun, "Taiwan rujing guanzhi chutan-yi Minguo sanshiba nian Chen Cheng danren shengzhuxi shi weili" (A preliminary research on entry restrictions in Taiwan-the instance of Chen Cheng as the Taiwan Provincial Governor in 1949), Guoshiguan xueshu jikan (Bulletin of Academia Historica), no. 1, 2001, pp. 225-253

74. Dominic Meng-hsuan Yang, "Wuling niandai waisheng zhongxia jieceng junmin zai Taiwan de shehui shi chutan-dangguo, jieji, shenfen liudong, shehui mailuo, jianlun waisheng da qianxi zai lisan yanjiu zhong de dingwei" (A preliminary study of the mid and lower class mainlanders in Taiwan in the 1950s — party-state, class, social mobility, social network, and discussion of the great mainland exodus in diaspora studies), in Chen Yi-shen et al., Zhonghua minguo liuwang Taiwan liushinian ji zhanhou Taiwan guoj chujing (The sixtieth anniversary of the Republic of China's exile in Taiwan and the international status of post-war Taiwan), Taipei, Qianwei, 2010, pp. 560-574. 
emotional attachments to the nationalist ideals of the KMT. The relationship between the migrant state and the migrant population was a complex historical process forged by circumstances in exile, and by the ruling strategy of the KMT. War and exile also influenced the lives and perspectives of waishengren in other important ways. A majority of civil war migrants left China in such an intense and dramatic fashion that they were deeply traumatised by the brutality of warfare as well as vivid memories of Communist persecution. Many arrived in Taiwan literally with only the clothes on their backs. As survivors of prolonged military conflicts and social chaos, the migrants had little tolerance for political instability on the island, and they assisted and supported, or in most cases, acquiesced to the persecution of political dissidents and suspected "leftists/Communists." For decades, waishengren helped sustain an authoritarian migrant regime, a regime backed by the United States, which many believed would take them back to mainland China. As a result, not only could the KMT suppress native Taiwanese political activists, but also purge a large number of mainlander dissidents and alleged "Communist spies" without arousing much discontent or resistance, all in the name of the sacred mission of mainland recovery.

For the same reason, exiles of the Chinese civil war showed little interest in local languages or cultures. They had very little sympathy for the political aspirations of Taiwanese dissidents, and they rarely thought about the consequences of their migration for indigenous society. Instead, they were deeply immersed in their own misery, nostalgia, and the crusade of mainland recovery. Moreover, years of bloody struggle against Japan had forged a strong nationalist sentiment that was profoundly anti-Japanese. This contributed to mainlanders' contempt, distrust, and even aversion toward the Japanese-educated native Taiwanese, whom the migrants thought were "enslaved" by the vicious influence of their former enemy. ${ }^{(75)}$ Many would suggest that "re-Sinicising" the local population was not only a practical necessity, but also a politically and morally justified undertaking. ${ }^{(76)}$ Meanwhile, native Taiwanese viewed the imposition of a new political/cultural regime and the condescending attitude of the mainlanders as "colonial," a subjective experience that is totally understandable due to their traumatic encounter with the "motherland." However it is important to recognise the specific historical context that gave rise to the KMT's language policy, as well as the sense of cultural superiority felt by mainlanders over the local population.

Despite the initial social and cultural divides between civil war migrants and the indigenous communities, decades of cohabitation, social interaction, and intermarriage have blurred the lines of division. As mentioned, the fieldwork of Li Kuang-chun demonstrated that many second generation waishengren spoke fluent Taiwanese. Furthermore, the imbalanced sex ratio among the exodus population, with many more men than women, meant that a large number of male migrants had to seek local companions. Among the non-military population, the ratio of males to females was approximately 2:1. If military personnel (the lowest estimate around $270,000)$ were included, the ratio could be as high as 3:1. ${ }^{(77)}$ According to data provided by multiple social surveys conducted since the mid-1980s, more than 50 percent of the male civil war migrants married native Taiwanese women. This would result in over half of the second-generation waishengren having native Taiwanese mothers. ${ }^{(78)}$ More recent surveys show that 88 percent $(7 / 8)$ of the waishengren married outside their own "ethnic group." (99)

Nevertheless, the relationship between intermarriage and assimilation has been much more complex than a simple causal effect. In 1993, Wang Fu-chang's research on "ethnic" intermarriage in post-war Taiwan demonstrated that while the children of these mixed marriages could speak better Taiwanese than those who had mainlander mothers, the process of assimilation was rather one-sided, with the native Taiwanese mothers and children accepting the views and identities of the mainlander fathers. ${ }^{\left({ }^{(8)}\right)}$ In a subsequent study published in 2001, Wang illustrated that second generation waishengren born in mixed-marriage families nevertheless showed a stronger tendency to identify with the social and cultural changes under indigenisation. ${ }^{\left({ }^{(8)}\right)}$ Wang's works suggest that

75. For "enslavement" or nuhua, refer back to note 22.

76. This sentiment is clearly demonstrated by numerous social commentaries on newspapers published in early post-war Taiwan. See Chen Fen, "Ribenhua daochu kewen" (Japanese could be heard everywhere), United Daily News, 11 November 1955, p. 5; Kung Shih, "Shancheng jinshuo riyu" (No speaking of Japanese in the mountain town), ibid., 16 November 1954, p. 5. For the re-Sinicisation policy in Taiwan during the retrocession period, see Huang Ying-che, Qu "Riben hua" zai "Zhongguo hua": zhanhou Taiwan wenhua chongjian, 1945-1947 (Uprooting Japan, implanting China: Cultural reconstruction in post-war Taiwan, 1945-1947), Taipei, Rye Field Publishing, 2007.

77. Li Tung-ming, "Jutai waishengji renkou zhi zucheng yu fenbu" (The profile of the mainlander population in Taiwan), Taipei Archives, no. 11/12, 1970, pp. 66-67.

78. Wang Fu-chang, "Zuqun tonghun de houguo: shengji tongxun duiyu zuqun tonghua de yingxiang" (The consequences of ethnic intermarriage: The impact of intermarriage on ethnic assimilation in Taiwan), Renwen ji shehuikexue jikan (Journal of Social Sciences and Philosophy), vol. 6, no. 1, 1993, p. 237.

79. Wang Fu-chang, "Taiwan zuqun tonghun yu zuqun guanxi zaitan" (A further investigation of ethnic marriages and ethnic relations in Taiwan), in Lau Siu-kai et. al. (eds.), Shehui zhuanxing yu wenhua bianmao: huaren shehui de bijiao (Social transformation and cultural change: Comparisons among Chinese societies), Hong Kong, the Chinese University of Hong Kong Institute of Asia-Pacific Studies, 2001, p. 417.

80. Wang Fu-chang, "Zuqun tonghun de houguo: shengji tongxun duiyu zuqun tonghua de yingxiang," art. cit., pp. 258-261.

81. Wang Fu-chang, "Taiwan zuqun tonghun yu zuqun guangxi zaitan," op. cit., p. 426. 
those who were born and raised in Taiwan were quite different from the exiled generation. At the same time, we also need to realise that many were still heavily influenced by the historical memories of their parents as well as their parents' perspective of an exilic Chinese/KMT national identity. The point is well demonstrated by the works of second-generation mainlander writers such as Chu Tien-hsin and Lung Ying-tai. ${ }^{\left({ }^{(2)}\right)}$ Finally, the third generation who grew up under indigenisation constitutes another cohort that needs to be studied in the future. All in all, the issue of generational difference requires further investigation through historical/diachronic analysis.

Historical/diachronic analysis can also help clarify some of the theories that have been proposed in mainlander studies, such as diaspora. Both Chao Yen-ning and Scott Simon make use of the term to theorise the experiences of waishengren in Taiwan. For Chao, the phenomenon is contemporary, since she analyses personal accounts given in the present. Meanwhile, Simon seems to suggest that first-generation Mainlanders already resembled diasporas as defined by William Safran during the early post-war years. ${ }^{\left({ }^{(3)}\right)}$ Historical evidence obtained from Free China (Ziyou Zhongguo) magazine (1949-1960) and the "reference magazines" (wenxian zazhi) produced by various "waisheng native place associations" (waisheng tongxianghui) starting in the early 1960s illustrates an important transition from "sojourn" (Iüjü) in the 1950s to "cultural nostalgia" (wenhua huaixiang) from the early 1960s onwards. The signing of the SinoAmerican Mutual Defense Treaty in 1954 and the Joint Communique of 1958, as a result of two Taiwan Strait Crises, effectively destroyed the KMT's hopes of a military incursion into mainland China with the support of the United States. ${ }^{(84)}$ This led to a fundamental change in the mentality of the liberal intellectuals associated with Free China magazine as they began to demand democratic reforms and prepared to establish an opposition party in 1960. These activities were promptly suppressed by the KMT. ${ }^{(85)}$ Right around the same time in 1962, the waisheng native place associations began producing a specific type of reference magazines centring on the history, geography, and local customs of their original hometowns and provinces along with the promotion of related cultural activities. Therefore, the early 1960s would probably serve as a better starting point to talk about the "diasporisation" of civil war migrants in Taiwan, not earlier.

All in all, waishengren began as a diverse group of political migrants who relocated to Taiwan 60 years ago because of the Chinese civil war. They came from different walks of life, spoke local dialects that were mutually incomprehensi- ble, and had rather diverse personal histories on the mainland. In Taiwan, the migrants and their offspring were not a homogenous community frozen in time, but were constantly changing and evolving in different ways. To gain a better understanding of the nuances of waishengren, we therefore propose a new broad-based research agenda taking a migrant perspective that will illuminate the importance of both history and agency.

Our proposal begins with a framework that considers the collective identity or "ethnicity" of the Mainlanders and the discursive label of "Waishengren" as a posteriori rather than a priori. Both the Mainlander community per se and the name(s) used to address them are the products of changing political and social circumstances in post-1945 Taiwan. By revisiting the past and making a distinction between the movement of people and the relocation of a political regime, we will find that waishengren had not been a homogenous exiled community attached to the KMT state, but a collectivity of diversities in terms of social class, subgroups, political ideas, and provincial identities. Therefore, attention should be paid to the experiences of different subgroups, different generations, and different individual subjects. The issues related to national identity, social/communal dislocation, imagination of homeland, state power, social inequality, and gender/sexuality must all be addressed. ${ }^{(86)}$ The methodology needs to be broad-based as well. Studies based on this new framework will employ archival records, media sources, memoirs/diaries, and oral history. Many existing subgroup studies tend to rely heavily on personal interviews and neglect archival research.

82. For more on Chu Tien-hsin, see R. Haddon's analysis of Chu's work Gudu (Ancient Capital, 1997). Rosemary Haddon, "Being/Not Being at Home in the Writing of Chu Tienhsin," in J. Makeham and A. Hsiau (eds.), Cultural, Ethnic, and Political Nationalism in Contemporary Taiwan, op cit., pp. 103-123.

83. S. Simon, "Taiwan's Mainlanders," art. cit., p. 5.

84. See Chang Su-ya, "Taihai weiji yu Meiguo dui fangong dalu zhengce de zhuanbian" (Taiwan Strait Crises and the US attitude toward "reconquering the Mainland" in the 1950s), Jindai shi yanjiusuo jikan (Bulletin of the Institute of Modern History, Academia Sinica), no. 36, 2001, pp. 231-297.

85. Free China fortnightly (1949-1960) was founded by a group of mainlander liberal intellectuals. The main participants included Hu Shih (1891-1962), Lei Chen (1897-1979), Yin Hai-kuang (1919-1969), and Fu Chen (1927-1991). Hu served as the nominal leader while Lei was charged with the task of running the magazine as chief editor. The liberals conceded to Chiang Kai-shek's dictatorship at first, seeing it as a wartime expediency. However, in the late 1950s, they began to demand political reforms that would put an end to a single-party rule. The magazine was shut down in 1960. Lei and Fu went to jail while the rest were cowed into submission. See Hsueh Hua-yuan, Ziyou zhongguo yu minzhu xianzheng: 1950 niandai Taiwan sixiang shi de yige kaocha (Free China and constitutional democracy: An investigation of the intellectual history of Taiwan during the 1950s), Banciao, Daoxiang chubanshe, 1996.

86. See Chang Mau-kuei, "Taiwan 'waishengren' congshu chuban zongxu” (Preface to the book series on mainlanders in Taiwan), in Chang Mau-kuei (ed.), Guojia yu rentong, op. cit., pp. I-VII. 
Rather than adopting an interpretive framework that promotes either the old KMT/Chinese nationalism or the new Taiwanese nationalism, the new scholarship should situate the history of waishengren in the greater international scholarship on migration and forced relocation. It must make an attempt to engage various concepts in migration studies such as refugees, exiles, sojourners, and diaspora. Under this overarching research agenda, the intricate relationships between the migrant state and the migrant community and between the migrant community and the local population must be examined and compared to other anti-Communist exilic communities in the twentieth century such as the Cubans and the Vietnamese. These comparisons will help tease out the commonalities and differences between the great mainlander exodus to Taiwan and other instances of political migration. ${ }^{(87)}$ In this way, waishengren studies in Taiwan will be able to contribute to the wider international scholarship, especially the study of political migrants.

\section{Conclusion}

The duality of waishengren as both "war refugees" and "outside colonisers" or "power-holders" and "disfranchised victims" offers an interesting case study for international scholarship on migration. While we have pointed out that many of the Mainlander studies in the past (ethnic relations/identity crisis approaches) neglected the history and the agency of the human subjects they tried to understand, scholars also need to be cautious not to over-focus diversity, making any discussion of collectivity impossible. Above all, the study of the diverse experiences of war, exile, and victimhood of many mainlanders should not lead us to turn a blind eye to the overall power structure in post-war Taiwan and the regulatory functions of the party-state in constructing inequalities and exclusions between different groups. It is important to recognise the fact that native Taiwanese and Aborigines had little choice but to accept the hierarchical political structure and the social and cultural realities brought upon them by the influx of waishengren and the political dominance of the KMT. When examining the past, we seek to understand the decisions made by historical agents under specific circumstances and junctures with empathy rather than passing politically-oriented judgments based upon the simple notion of ethnic division. The same perspective can be applied to the study of the resistance and collaboration of native Taiwanese and Aborigines under KMT rule. In sum, we submit that the theorisation of the mainlander communitie(s) and identitie(s) requires a broad-based historical and sociological in- quiry grounded solidly in both archival research and ethnographic fieldwork. Such an inquiry will help us gain a better understanding of the political, economic, and social divides in post-war Taiwan, as well as of the shifting boundaries and changing nature of these divisions both in the past and at the present time.

\section{Glossary}

a shan 阿山 baise kongbu白色恐怖 bendiren 本地人 bensheng 本省 bentuhua 本土化 Chang Tien-wan 張典婉 Chen Cheng 陳誠 Chen Shui-bian 陳水扁 Chi Pang-yuan 齊邦媛 Chiang Ching-kuo 蔣經國 Dajiang dahai 1949 大江大海 1949 dalu ren 大陸人 gauki dilai 狗去猪來 (in Hoklo) guojia zhengce yanjiu zhongxin 國家政策研究中心 Hakka/Kejia 客家Hoklo/Minnan 鶴佬(福佬)/閩南 Hualien 花蓮 jiguan 籍貫 juancun 眷村 Jüliu he 巨流河 Lai Sheng-chuan 賴熬川 laobing 老兵 Lee Teng-hui 李登輝 lisan 離散 liuwang de zigong 流亡的子宫 lüjü 旅居 Lung Ying-tai 龍應台 National Dong Hwa University 國立東華大學 neidi ren 內地人 nuhua 奴化 Penghu 澎湖

Pingpuzu/Pepo 平埔族 Qinmin dang 親民黨

Shandong liuwang xuesheng 山東流亡學生

sida zuqun 四大族群 tangshan 唐山 waisheng 外省

Waishengren/waishengren 外省人

Waisheng Taiwanren xiehui 外省台灣人協會 waisheng tongxianghui 外省同鄉會

Wang Wei-chung 王偉忠 wailai zhimin zhengquan 外來殖民政權 wenhua huaixiang 文化懷鄉 wenxian zazhi 文獻雜誌 xiajiang ren 下江人 Xin dang 新黨 xin Zhongguo 新中國 xunren qishi 寻人啟事 Xunzhao Taiping lun 寻找太平輪 yijiazi 一甲子

yi Taiwan wei zhongxin de lishi 以台灣為中心的歷史

Yuanzhumin 原住民

zimou shenghuo laobing 自謀生活老兵

Ziyou Zhongguo 自由中國 zuqun 族群

zuqun guanxi yanjiu 族群關係研究

87. One of the most important differences between the mainlanders and Cubans/Vietnamese is that the former migrated with an authoritarian regime within their own "imagined" national borders while the latter relocated to a foreign country (the United States or various Western countries) and became ethnic minorities. What is interesting in the case of mainlander is that because of 50 years of Japanese colonialism, the cultural and linguistic barriers created an environment that was like a "foreign country" for waishengren when they set foot on the island. 